\title{
Influencing factors on planning decision- making among Spanish in-service Physical Education teachers.A population-based study
}

\author{
Jesús Viciana $^{1}$, Daniel Mayorga-Vega ${ }^{1}$
}

${ }^{1}$ Departamento de Educación Física y Deportiva, Universidad de Granada

\section{España}

Correspondencia: Jesús Viciana, Departamento de Educación Física y Deportiva de la Universidad de Granada, Ctra. Alfacar s/n, 18011, Granada, España E-mail: jviciana@ugr.es 


\section{Abstract}

Introduction. Traditionally, literature has contributed qualitative approaches for studying how to plan Physical Education (PE). To our knowledge there are not quantitative populationbased studies regarding the decision-making process among in-service Spanish PE teachers. The aim of this study was to analyze possible differences in the factors of influence on planning decision-making in PE with a large sample of Spanish in-service teachers depending on their characteristics (gender, teaching experience) and the educational context (educational stage, type of school).

Method. The sample consisted of 618 teachers from 15 Spanish autonomous regions (422 males and 196 females; aged 23-63 years old). An electronic version of the validated Planning Decision-Making in PE Questionnaire was applied, using the google web platform. It is composed of eight factors (curriculum standards, pre-service training, physical environment, physical activity experiences, teaching experiences, socialization by other teachers, material and equipment, and level of preparation in the subject matters).

Results. The results showed differences regarding the factors of influence in planning PE between teachers, caused by personal (teaching experience) and contextual (educational stage and type of school) factors. Habitual physical activity and pre-service training influenced novel teachers more in comparison to experienced teachers. Teachers from secondary schools were influenced more by their initial training, the curriculum standards, and the material and equipment. Public school teachers were more influenced by the curriculum standards and the physical environment, than those from private schools.

Conclusion. According to previous qualitative research regarding the level of teaching experience, results suggest that initial training for PE teachers should consider including higher support from experienced teachers in order to avoid the dependence on the national curriculum standards. It is important to include the use of the physical environment of the school center regarding the effect that outdoor activities have on the students' physical activity habits in their leisure time.

Keywords: Cross-sectional study, cross-sectional survey, teachers' perspective, secondary, primary. 


\section{Resumen}

Introducción. La literatura ha contribuido tradicionalmente con trabajos cualitativos para abordar el estudio de cómo se planifica la Educación Física. No se conocen estudios cuantitativos con grandes muestras en relación al proceso de toma de decisiones con profesores españoles en servicio de Educación Física (EF), dependiendo de sus características (género y experiencia docente) y del contexto educativo (etapa educativa y tipo de centro).

Método. La muetra consistión en 618 profesores en servicio de 15 comunidades autónomas españolas (422 hombres y 196 mujeres; con edades de entre 23-63 años). Se aplicó una versión electronica del cuestionario CIPEF (Cuestionario de Influencia en la Planificación de la Educación Física).

Resultados. Los resultados mostraton diferencias en relación a los factores de influencia al planificar la EF entre profesores, debido a sus factores personales (experiencia educativa) y contextuales (etapa educativa y tipo de centro). La actividad física habitual y la formación inicial influyeron a los profesores noveles más que a los experimentados. Los profesores de secundaria fueron más influidos por su formación inicial, los estándares curriculares y el material y las instalaciones del centro. Los profesores de centros públicos se influyeron más por los estándares curriculares y el entorno físico del centro que los de centros privados.

Conclusiones. De acuerdo a la literatura previa, los resutlados de este estudio sugieren que la formación incial debería incluir un mayor apoyo de profesores experimentados para evitar la dependencia de los estándares curriculares a los profesores en formación. Igualmente, es importante incluir el uso del entorno físico del centro en la planificación, dada la relación entre realizar actividades al aire libre y el incremento de la actividad física habitual en los estudiantes durante su tiempo libre.

Palabras Clave: Estudio seccional transversal, encuesta seccional transversal, perspectiva del profesorado, secundaria, primaria 


\section{Introduction}

The decision-making process that supposes the planning in an educational context is based on the characteristics and necessities that each educational group needs (e.g., age, number, and characteristics of students; curriculum requirements; teachers' preferences or sports facilities) (Viciana, Blanco, \& Mayorga-Vega, 2015). These decisions have been previously studied in literature, assuming that teachers do in the classroom what they are thinking preceding their decision-making process when planning (Clark \& Yinger, 1987), being an important issue for educational scientists for several decades (Clark \& Peterson, 1986; Housner \& Griffey, 1985). The cognitive mediational paradigm has studied, normally from a qualitative approach, what these decisions are, and explaining teachers' principles of procedure in their particular contexts (Timken \& Mars, 2009). Despite qualitative methodology allows researchers understand, explain and provide solutions to practical teaching problems, it does not allow to analyze wider samples than several cases, and consequently it does not allow to generalize teaching actuations regarding those decisions, nor to identify the influential factors according to different teachers' characteristics or different scholar settings (Viciana et al., 2015).

Moreover, Physical Education (PE) is very special, with multiple conditions that depend on a large number of contextual factors and teachers' decisions. Thus, physical educators make their curricular decisions mainly influenced by their educational beliefs and value orientations (Pajares, 1992) that determine, in part, the kind of PE that teachers implement in schools (Ennis, 1994). In fact, the limitation of teachers' beliefs showing little relation to PE practices used in the classroom has been commented in literature (Wilcox-Herzog, 2003). Therefore, the decisional process of PE planning depends on interdependent factors and seems to be complex. For instance, being an experienced or inexperienced teacher influences on planning in a different way. Research showed that experienced teachers are more concerned in their planning (Housner \& Griffey, 1985); ask questions linked with students, facilities and equipment (Griffey \& Housner, 1991); and spend less time for planning (mainly focused on the flow of the lessons and not on the finer details of an individual lesson) than inexperienced teachers (Borko et al., 1986). On the contrary, inexperienced teachers, for instance, are more influenced by the pre-service training (Van der Berg, 2002), and are more centered on individual lessons than on the global process of planning (Borko et al., 1986). Related to the ini- 
tial training and experiences in teaching, the concept of the alignment of teachers' instructions with national standards, for instance, is another influential planning factor recently studied (MacPhail, Tannehill, \& Karp, 2013; Polikoff, 2013). Other factors that could influence teachers' decisions in the PE planning are positives experiences such as their actual practices of physical activity during their leisure time (Juliusson, Karlsson, \& Gärling, 2005), the material and equipment available in the PE department (O'Hara, Reis, Esteves, Bras, \& Branco, 2011) or the physical environment around the educational center (Ehlers, Huberty, \& Beseler, 2013).

Due to the lack of studies with large samples analyzing the decisional process of planning PE and due to the necessity of taking into account all the considerations mentioned above as potential influential factors, Viciana et al. (2015) developed the CIPEF questionnaire (for its initials in Spanish: Cuestionario de Influencia en la Planificación de la Educación Física [Factors of Influence in planning Physical Education questionnaire]). Therefore, since the development of the CIPEF instrument it is possible to study large samples of teachers to a better understanding of the decision-making process of planning PE in Spanish population.

\section{Aims and Hypothesis}

Consequently, the aim of this study was to analyze possible differences in the factors of influence on planning decision-making in PE in a large sample of Spanish in-service teachers depending on their characteristics (gender and teaching experience) and the educational context (educational stage and type of school). Due to the previous qualitative studies mentioned above, personal and contextual characteristics will influence on planning decision making in PE.

\section{Method}

\section{Participants}

All PE teachers from 15 Spanish regions were invited to participate in the present study. A sample of 618 Spanish PE teachers, 422 males and 196 females, aged 23-63 years old $(M=40.42 \pm 8.24$ years $)$ participated in the present study. Participants were in-service PE teachers that were teaching in elementary and/or secondary schools, with a teaching experi- 
ence that ranged from 0 to 42 years $(M=14.60 \pm 8.82$ years). The Ethical Committee of the University of Granada (Spain) Papproved this study.

\section{Instruments}

The CIPEF questionnaire is original from Viciana et al. (2015), and it measures the degree of influence of multiple decision-making factors in the planning of PE. It is composed of 29 items and eight factors: (a) curriculum standards (influence of the national curriculum standards on the decision-making process of planning PE); (b) pre-service training (regarding the influence of the curricular practices that teachers experienced during their degree such as methodology, notes, practical sessions, or theory and information); (c) physical environment (influence of the environment around the center on the way of planning PE); (d) physical activity experiences (influence of teachers' habitual physical activity experiences in their planning); e) teaching experiences (influence of the years of experience in planning PE); physical activity experiences (influence of the actual practice of physical activity on planning PE); (f) socialization by other teachers (this factor deals with the influence of other teachers on how to plan PE such as shared ideas, team group planning or experiences of other teachers); (g) material and equipment (regarding the influence of the quantity and quality of specific materials of $\mathrm{PE}$ and equipment available for planning PE), and (h) level of preparation in the subject matters (this factor deals with the influence of the self-perception of teachers about their level of preparation in the subject matters, their knowledge and level of expertise). Items were rated on a 6-Likert scale from 1 ("Totally disagree") to 6 ("Totally agree") (e.g., "The information I received in my Faculty influence my way of planning PE"). The CIPEF questionnaire presented good validity $(\mathrm{CFI}=.904 ; \mathrm{GFI}=.857 ; \mathrm{RMSEA}=.061)$ and reliability indices (Cronbach's Alpha coefficients between .79 and .89) (Viciana et al., 2015).

\section{Procedure}

On one hand, the validated version of the CIPEF questionnaire was created in a computerized form, using the Google web platform, in order to be sent to all the elementary and secondary school centers of Spain. A first page of the questionnaire informed about the intention of the study, asked the sincerity of their opinions, and guaranteed the anonymity of the responses. Then, all the teachers' characteristics (gender, age, and teaching experience) and their educational context (educational stage and type of school) were asked. 
On the other hand, all school centers belonging to elementary and secondary schools mails were recruited from the Government web page of all the geographical communities of Spain. Each of the 19 Spanish communities (17 autonomous regions and 2 autonomous cities) has their own politician regarding Education, and after consulting their web pages and calling them by phone in order to get the e-mail address of all of the school centers, 15 of the 19 autonomous communities were collected, except Madrid, Cataluña, Valencia, Cantabria, and Galicia. Then, an e-mail was sent to the principal of the school center in order to inform him/ her about the aim of the study and to request his/ her collaboration with the research (resending the email to all the PE teachers and asking them for their collaboration). Finally, all data were generated and collected by the computerized application.

\section{Data Analysis}

Descriptive statistics (mean and standard deviation) for all the dependent variables were calculated. A one-way multivariate analysis of covariance (MANCOVA) was used to test the differences on the influence of the CIPEF dimensions on PE teachers according to their gender, teaching experience, educational stage and type of school. Then, significant multivariate analyses were followed up with the univariate analyses of covariance (ANCOVA). Additionally, for the experience variable, a post-hoc with the Bonferroni adjustment was used for the between-groups pairwise comparisons. Beforehand, according to Fernández-Cruz (1995), teachers' teaching experience was categorized as low (0-3 years), moderate (4-12 years) and high (> 12 years). Effect sizes were estimated using the partial eta squared $\left(\eta^{2}\right)$. The reliability of the CIPEF dimensions was estimated using the intraclass correlation coefficient from two-way ANOVA ( $\mathrm{ICC}_{3, \mathrm{k}}$ ) and a 95\% confidence interval (Shrout \& Fleiss, 1979). All statistical analyses were performed using the SPSS Version 21.0 for Windows (IBM® SPSS $®$ Statistics). The statistical significance level was set at $p<0.05$.

\section{Results}

Although a total of 628 cases were registered, 10 cases were deleted because of duplication issues. The reliability results obtained in the CIPEF dimensions was very good (ICC 95\% IC-): pre-service training 0.891 (0.877-0.904); level of preparation in the subject matters 0.931 (0.919-0.941); curriculum standard 0.952 (0.946-0.958); physical environment 0.901 (0.888-0.913); physical activity experiences 0.910 (0.897-0.922); teaching experiences 0.901 
(0.888-0.913); materials and equipment 0.821 (0.795-0.844), and socialization by other teachers $0.859(0.839-0.878)$.

\section{Gender}

Table 1 shows descriptive statistics (mean and standard deviation) and the MANCOVA results on CIPEF scores between male and female teachers. The one-way MANCOVA result did not indicate overall statistically significant differences on CIPEF scores between male and female teachers (Wilks' $\lambda=0.983 ; \mathrm{F}_{8,606}=1.286 ; p=0.248$ ). Moreover, the followup one-way ANCOVAs neither revealed statistically significant differences on any of the CIPEF dimensions.

Table 1. Differences on planning decision-making in Physical Education questionnaire (CIPEF) scores between male and female teachers

\begin{tabular}{|c|c|c|c|c|c|c|c|}
\hline & \multicolumn{2}{|c|}{ Males $(n=422)$} & \multicolumn{2}{|c|}{ Females $(n=196)$} & \multicolumn{3}{|c|}{$\mathrm{MANCOVA} \mathrm{ANCOVA}^{\mathrm{a}}$} \\
\hline & $M$ & $(S D)$ & $M$ & $(S D)$ & $F$ & $p$ & $\eta_{\mathrm{p}}^{2}$ \\
\hline CIPEF & & & & & 1.286 & 0.248 & 0.017 \\
\hline Pre-service training & 3.20 & $(1.16)$ & 3.14 & $(1.11)$ & 0.952 & 0.330 & 0.002 \\
\hline $\begin{array}{l}\text { Level of preparation in } \\
\text { subject matters }\end{array}$ & 4.44 & $(1.19)$ & 4.56 & $(1.25)$ & 1.672 & 0.197 & 0.003 \\
\hline Curriculum standards & 3.91 & $(1.20)$ & 4.01 & $(1.09)$ & 0.498 & 0.481 & 0.001 \\
\hline Physical environment & 4.58 & $(1.09)$ & 4.59 & $(1.07)$ & 0.026 & 0.871 & 0.000 \\
\hline $\begin{array}{l}\text { Physical activity experi- } \\
\text { ences }\end{array}$ & 3.11 & $(1.28)$ & 3.17 & $(1.29)$ & 0.359 & 0.549 & 0.001 \\
\hline Teaching experiences & 5.32 & $(0.70)$ & 5.32 & $(0.84)$ & 0.009 & 0.923 & 0.000 \\
\hline Material and equipment & 4.90 & $(0.91)$ & 5.02 & $(0.89)$ & 2.531 & 0.112 & 0.004 \\
\hline $\begin{array}{l}\text { Socialization by another } \\
\text { teachers }\end{array}$ & 4.36 & $(1.09)$ & 4.53 & $(1.08)$ & 2.912 & 0.088 & 0.005 \\
\hline
\end{tabular}

Note. $M=$ mean; $S D=$ standard deviation; ${ }^{\mathrm{a} O n e-w a y ~ m u l t i v a r i a t e ~ a n a l y s i s ~ o f ~ c o v a r i a n c e ~ f o l l o w e d ~ u p ~ b y ~ t h e ~ o n e-w a y ~}$ univariate analyses of covariance. 


\section{Teaching Experience}

Table 2 shows descriptive statistics (mean and standard deviation) and the MANCOVA results on CIPEF scores between teachers with low, moderate and high experience. The one-way MANCOVA result indicated overall statistically significant differences on CIPEF scores between teachers with different levels of experience (Wilks' $\lambda=0.955 ; F_{16,1210}$ $=1.766 ; p=0.031)$. The follow-up one-way ANCOVA's results showed that pre-service training and physical activity experiences dimensions had a statistically significant influence on teachers according to their teaching experience $(p<0.05)$. Particularly, the post-hoc between-group pairwise comparisons with the Bonferroni adjustment showed that the preservice training dimension had a statistically significantly greater influence on teachers with low experience than those with high experience $(p<0.05)$. Regarding the physical activity experiences dimension, the results of the between-group pairwise comparisons showed that it had a statistically significantly higher influence for teachers with low experience than those with moderate teaching experience $(p<0.05)$. The follow-up ANCOVAs did not reveal statistically significant differences on the other CIPEF dimensions $(p>0.05)$.

Table 2. Differences on planning decision-making in Physical Education questionnaire (CIPEF) scores between teachers with low (1-3 years), moderate (4-12 years) and high (>12 years) experience

\begin{tabular}{|c|c|c|c|c|c|c|c|c|c|}
\hline & \multicolumn{2}{|c|}{$\begin{array}{c}\text { Low } \\
(n=49)\end{array}$} & \multicolumn{2}{|c|}{$\begin{array}{l}\text { Moderate } \\
(n=247)\end{array}$} & \multicolumn{2}{|c|}{$\begin{array}{c}\text { High } \\
(n=322)\end{array}$} & \multicolumn{3}{|c|}{$\begin{array}{l}\text { MANCOVA/ AN- } \\
\text { COVA }^{\mathrm{a}}\end{array}$} \\
\hline & $M$ & $(S D)$ & $M$ & $(S D)$ & $M$ & $(S D)$ & $F$ & $p$ & $\eta_{\mathrm{p}}^{2}$ \\
\hline CIPEF & & & & & & & 1.766 & 0.031 & 0.023 \\
\hline Pre-service training & 3.54 & $(1.20)$ & 3.26 & $(1.10)$ & 3.06 & $(1.16) \dagger$ & 4.608 & 0.010 & 0.015 \\
\hline $\begin{array}{l}\text { Level of preparation in } \\
\text { subject matters }\end{array}$ & 4.47 & $(1.21)$ & 4.44 & $(1.17)$ & 4.50 & $(1.24)$ & 0.189 & 0.828 & 0.001 \\
\hline Curriculum standards & 4.17 & $(0.87)$ & 3.98 & $(1.17)$ & 3.88 & $(1.20)$ & 2.237 & 0.108 & 0.007 \\
\hline Physical environment & 4.77 & $(1.14)$ & 4.57 & (1.09) & 4.57 & $(1.07)$ & 1.496 & 0.225 & 0.005 \\
\hline $\begin{array}{l}\text { Physical activity experi- } \\
\text { ences }\end{array}$ & 3.58 & $(1.33)$ & 3.06 & $(1.21)^{*}$ & 3.11 & $(1.32)$ & 3.231 & 0.040 & 0.010 \\
\hline Teaching experiences & 5.34 & $(0.67)$ & 5.31 & $(0.74)$ & 5.32 & $(0.76)$ & 0.100 & 0.905 & 0.000 \\
\hline Material and equipment & 4.97 & $(0.76)$ & 4.84 & $(0.95)$ & 5.00 & $(0.88)$ & 1.852 & 0.158 & 0.006 \\
\hline Socialization by another & 4.54 & $(0.95)$ & 4.40 & $(1.06)$ & 4.42 & $(1.13)$ & 0.351 & 0.704 & 0.001 \\
\hline
\end{tabular}


teachers

Note. $M=$ mean; $S D=$ standard deviation; ${ }^{a}$ One-way multivariate analysis of covariance followed up by the one-way univariate analyses of covariance; post-hoc pairwise comparisons with Bonferroni adjustment for between-groups analyses: * $<0.05$ for 1 3 years/4-12years and $\dagger p<0.05$ for $1-3$ years/ $>12$ years.

\section{Educational Stage}

Table 3 shows descriptive statistics (mean and standard deviation) and the MANCOVA results on CIPEF scores between teachers from elementary and secondary schools. Since some teachers taught in both educational stages, the overall $n$ is lower. The one-way MANCOVA result indicated overall statistically significant differences on CIPEF scores between teachers from elementary and secondary schools (Wilks' $\lambda=0.953 ; F_{8,577}=3.591 ; p<$ 0.001). Then, the one-way ANCOVAs results showed that pre-service training, curriculum standards, and material and equipment dimensions had a statistically significantly higher influence in teachers from secondary schools than those from elementary schools $(p<0.05)$. However, the follow-up ANCOVAs did not reveal statistically significant differences on the other CIPEF dimensions ( $p>0.05)$.

Table 3. Differences on planning decision-making in Physical Education questionnaire (CIPEF) scores between teachers from elementary and secondary schools

\begin{tabular}{lccccccc}
\hline & \multicolumn{2}{c}{$\begin{array}{c}\text { Elementary } \\
(n=362)\end{array}$} & \multicolumn{2}{c}{$\begin{array}{c}\text { Secondary } \\
(n=227)\end{array}$} & \multicolumn{2}{c}{ MANCOVA/ ANCOVA $^{\mathrm{a}}$} \\
\cline { 2 - 7 } & $M$ & $(S D)$ & $M$ & $(S D)$ & $F$ & $p$ & $\eta^{2} \mathrm{p}$ \\
\hline $\begin{array}{l}M I P E F \\
\text { Pre-service training }\end{array}$ & 3.03 & $(1.15)$ & 3.36 & $(1.11)$ & 15.621 & $<0.001$ & 0.026 \\
Level of preparation in & 4.45 & $(1.20)$ & 4.51 & $(1.24)$ & 0.101 & 0.751 & 0.000 \\
subject matters & & & & & & & \\
Curriculum standards & 3.84 & $(1.20)$ & 4.10 & $(1.11)$ & 9.042 & 0.003 & 0.015 \\
$\begin{array}{l}\text { Physical environment } \\
\text { Physical activity experi- }\end{array}$ & 4.59 & $(1.08)$ & 4.55 & $(1.09)$ & 0.000 & 0.994 & 0.000 \\
ences & 3.16 & $(1.29)$ & 3.08 & $(1.28)$ & 0.864 & 0.353 & 0.001 \\
Teaching experiences & 5.31 & $(0.74)$ & 5.31 & $(0.76)$ & 0.019 & 0.890 & 0.000 \\
Material and equipment & 4.86 & $(0.96)$ & 5.04 & $(0.82)$ & 4.511 & 0.034 & 0.008
\end{tabular}


Socialization by another teachers
4.41
(1.09)
4.44
(1.07)
0.183
0.669
0.000

Note. $M=$ mean; $S D=$ standard deviation; ${ }^{a}$ One-way multivariate analysis of covariance followed up by the one-way univariate analyses of covariance.

\section{Type of School}

Table 4 shows descriptive statistics (mean and standard deviation) and the MANCOVA results on CIPEF scores between teachers from public and private schools. The oneway MANCOVA result indicated overall statistically significant differences on CIPEF scores between teachers from public and private schools (Wilks' $\lambda=0.957 ; F_{8,606}=3.406 ; p=$ 0.001). Subsequently, the one-way ANCOVAs results showed that curriculum standards and physical environment dimensions had a statistically significantly greater influence in teachers from public schools than those from private schools $(p<0.05)$. The follow-up ANOVAs did not reveal statistically significant differences on the other CIPEF dimensions $(p>0.05)$.

Table 4. Differences on planning decision-making in Physical Education questionnaire (CIPEF) scores between teachers from public and private schools

\begin{tabular}{lccccccc}
\hline & \multicolumn{2}{c}{ Public $(n=499)$} & \multicolumn{2}{c}{ Private $(n=119)$} & \multicolumn{3}{c}{ MANCOVA/ ANCOVA $^{\mathrm{a}}$} \\
\cline { 2 - 7 } & $M$ & $(S D)$ & $M$ & $(S D)$ & $F$ & $p$ & $\eta^{2} \mathrm{p}$ \\
\hline CIPEF & & & & & 3.406 & 0.001 & 0.043 \\
Pre-service training & 3.12 & $(1.17)$ & 3.43 & $(1.02)$ & 1.783 & 0.182 & 0.003 \\
Level of preparation in & 4.48 & $(1.24)$ & 4.48 & $(1.09)$ & 0.047 & 0.829 & 0.000 \\
subject matters & 3.98 & $(1.19)$ & 3.80 & $(1.04)$ & 4.550 & 0.033 & 0.007 \\
Curriculum standards & 4.66 & $(1.05)$ & 4.26 & $(1.14)$ & 16.221 & $<0.001$ & 0.026 \\
$\begin{array}{l}\text { Physical environment } \\
\text { Physical activity experi- }\end{array}$ & 3.10 & $(1.31)$ & 3.23 & $(1.15)$ & 1.256 & 0.263 & 0.002 \\
ences & & & & & & & \\
Teaching experiences & 5.34 & $(0.73)$ & 5.22 & $(0.81)$ & 3.115 & 0.078 & 0.005 \\
Material and equipment & 4.94 & $(0.90)$ & 4.91 & $(0.95)$ & 0.146 & 0.703 & 0.000 \\
Socialization by another & 4.45 & $(1.08)$ & 4.27 & $(1.11)$ & 2.707 & 0.100 & 0.004 \\
teachers & & & & & & & \\
\hline
\end{tabular}

Note. $M=$ mean; $S D=$ standard deviation; ${ }^{\mathrm{a} O n e}$-way multivariate analysis of covariance followed up by the one-way 
univariate analyses of covariance.

\section{Discussion}

The aim of this study was to analyze possible differences in the factors of influence on planning decision-making in PE in a large sample among Spanish in-service teachers depending on their characteristics (gender and teaching experience) and contextual factors (educational stage, and type of school).

According to the dimensions measured by the CIPEF questionnaire, results showed that gender was not an influential factor of planning for Spanish in-service PE teachers. However, as previous research has reflected in literature, gender could be an influential factor depending on the research approach and the participants. Thus, in a case study carried out by Pissanos and Allison (1993) for instance, they found greater details in the explanations made by female teachers and more variety of reasons provided regarding their decisions when planning sport curricula in elementary schools. Nevertheless, these types of studies usually report results based on qualitative data, and in this above commented study, the results did not mean that male and female teachers planned in a different way, but that they reported different explanations for their planning. Moreover, in studies centered on the preferences of particular contents in the PE of teachers and students, differences were found regarding gender showing that males and females preferred sports and expression contents, respectively (Castejón \& Giménez, 2015). The CIPEF questionnaire does not detect differences in the type of content planned by PE teachers, but in the factors that could influence in the planning of it (content or any other element belonging to planning that are not specified in the questionnaire). For instance, results regarding gender showed no differences in the dimension "level of preparation in subject contents", which supposes that female and male teachers did not consider planning one content or another in their PE due to the better preparation they had in those contents.

However, regarding the teaching experience, results showed significant differences in the planning of in-service Spanish PE teachers, as previous research found (Kim \& Housner, 2010). Teachers with less experience in teaching were more influenced by their initial training and their experiences in their habitual physical activity when planning PE. Matanin and Collier (2003), for instance, detected that life customs and personal baggage of novel PE teachers (with less teaching experience) influenced their beliefs and their view of the PE. Moreover, it 
is probable that due to novel teachers' lack of experience causing deficiency of security and control, they use their pre-service training contents and their experiences in their internship as a support for their first years of teaching and planning (Matanin \& Collier, 2003). This idea is maintained by Rimm-Kauffman (2006) who defends that pre-service teachers give priority to the beliefs that come from their experiences as students in secondary and university levels. On the contrary, experienced teachers based their instructions on the day-by-day experiences with their students, influencing more when they had more experience. Del Villar (1993) also confirmed these results in a study of cases in which teachers with less experience teaching were more "dependent" on the national curriculum guidelines and their experiences as university students. Consequently, it seems that pre-service teacher training should be based on a higher support from experienced teachers regarding pedagogical content knowledge, curriculum design and curricular consistency, as commented by Huizinga, Handelzalts, Nieveen, and Voogt (2014).

Regarding the educational stage, teachers from secondary schools were more influenced by their initial training, the curriculum standards, and the available material and equipment of the school center than those from elementary schools. As Sicilia, Sáenz-López, Manzano and Delgado (2009) commented, the curricular differences between the educational stages of elementary and secondary levels produce clear differences between these two groups of teachers regarding the priority given to educational finalities, the selection of PE contents, and the way of intervening in the classroom. The higher specific development of the curriculum in the secondary level of teaching seems to be a determinant factor regarding the PE planning (Behets \& Vergauwen, 2004). Initial teacher training could help teachers, acting as a support for a more effective and successful planning in this educational stage of the secondary level, probably due to the difficulty of planning complex tasks for advanced students, and with more specific contents compared with the students from elementary level. Moreover, material and equipment available at the school center could allow PE teachers to develop a great variety of PE matters and contents, as the curriculum requests of them, or could also restrict them in the practical application of the curriculum. On the contrary, teachers from the elementary school level could develop a more general curriculum centered on basic abilities and fundamental motor skills that could be developed without specific materials, or with multiuse material and basic facilities, without constrains from specific and complex contents (Viciana \& Mayorga-Vega, 2013). The same reason could be attributed to a less influence of the 
national curriculum in elementary PE teachers, which is a more opened and general curriculum than that of the secondary level. This seems to cause more of a dependence on the curriculum standards for PE teachers from the secondary level than those from the elementary level.

Regarding the type of school, results of this study detected differences between teachers from public and private schools, public school teachers being more influenced by the curriculum standards and physical environment of the school center than private school teachers when planning PE. Teaching in private schools could be less influenced by curriculum standards due to the characteristics of Spanish private schools, associated to values, beliefs, religion, and ideology in general (Martínez-Torrón, 2012), which could relegate the national regulations regarding the standards in PE to a secondary level. Unfortunately, no references in literature have been found regarding the effect of Spanish private or public schools on the use of the environment of an educational center or regarding the initial training. Nevertheless, characteristics of Spanish private schools are associated to more control of the students and to taking less risk to organize outdoor activities in PE. In a recent study, Silva, Sousa, Sá, Ribeiro and Mota (2015) stated that the natural environment of the school center is an important factor for maintaining an active lifestyle in scholars, mainly being fundamental in rural schools. On the contrary, urban and private schools have been suggested as influential factors for a less active lifestyle for scholars (Joens-Matre et al., 2008). Due to the results obtained in the present study, the difference in the way of planning PE, which depending on the type of school and together with the fact that outdoor activities cause a higher motivation (Hubball \& West, 2009) and learning (Pasek, Michalowska-Sawczyn, \& Nowak-Zaleska, 2014) in students, are probably good reasons for recommending the introduction of the use of environment in the PE curriculum of any type of school (i.e., private-public or rural-urban), in order to achieve higher levels of physical activity and a better lifestyle for scholars. The transcontextual model of Hagger and Chatzisarantis (2016) confirmed the connection between PE lessons and out-of-school physical activity. Consequently, to make teachers aware of the importance of planning PE using the physical environment of public and private schools is a crucial element for PE teacher educational programs. This is particularly important in regard to the effect that outdoor activities incorporated into the PE curriculum in early ages contribute to a lasting effect and consequently lifelong benefits (The Outdoor Foundation, 2013), and also contribute to many other national standards [e.g., social and personal responsibility, team working, and situational and self-learning (Hubball \& West, 2009)]. 
To study a large sample of in-service PE teachers, with the first application of the CIPEF questionnaire in Spain, supposes an important strength to this research, but it is also necessary to consider the limitation that five autonomous regions from Spain did not participate in the study. The use of discussion groups and other qualitative techniques of data collection could provide support and explanations to the findings found in this research in a future stage.

\section{Conclusions}

This article provides a Spanish population-based study, which supposes a different approach to PE planning and provides a more global view regarding the factors of influence of PE teachers' when planning the PE. Our findings suggest that the teaching experience, educational stage, and type of school influence PE teachers' planning and they need to be taken into account in the teachers training. According to previous qualitative research regarding the level of teaching experience, results suggest that pre-service training for PE teachers should consider including the collaboration of experienced teachers in order to make inexperienced teachers more autonomous and independent regarding the theory and legislation of PE curriculum. Moreover, providing enough and specific material and facilities to school centers is required in order to avoid restrictions for teachers when planning PE, mainly in secondary schools, where the complexity and curriculum specifications suggest PE teachers planning more specific tasks and contents. Results suggest that developing a more opened PE is required for teachers from private schools, regarding the use of the physical environment of the school center. It is an important issue in regard with providing students enough autonomy to regulate their physical activity in their leisure time, fostering a healthier style of life. The typical control and beliefs-oriented curriculum in private schools could be a crucial factor in the lack of outdoor activities and using the physical environment of the school center in PE. A next stage of this study is needed in order to go into detail about these findings.

\section{Acnowledgments}

Authors want to thank Aliisa Hatten for the English revision of the manuscript. 


\section{References}

Behets, D., \& Vergauwen, L. (2004). Value orientations of elementary and secondary physical education teachers in Flanders. Research Quarterly for Exercise and Sport, 75(2), 156-164. http://dx.doi.org/10.1177/1356336X15596984

Borko, H., Lalik, R., Livingston, C., Pecic, K., \& Perry, D. (1986, April). Learning to teach in the induction year: Two case studies. Paper presented at the annual meeting of the American Educational Research Association, San Francisco, CA.

Castejón, F.J., \& Giménez, F.J. (2015). Teachers' perceptions of physical education content and influences on gender differences. Motriz, 21(4), 375-385.

Clark, C.M., \& Peterson, P.L. (1986). Teachers' thought processes. In M. C. Wittrock (Ed.), Handbook of research on teaching (3rd ed., pp. 255-296). New York: Macmillan.

Clark, C.M., \& Yinger, R. (1987). Teacher planning. In J. Calderhead (Ed.), Exploring teachers' thinking (pp. 84-103). London: McKay.

Del Villar, F. (1993). Desarrollo del conocimiento práctico de los profesores de Educación Física a través de un programa de análisis de la práctica docente. Un estudio de casos en formación inicial (Unpublished doctoral dissertation). University of Granada. Spain.

Ehlers, D.K., Huberty, J.L., \& Beseler, C.L. (2013). Is school community readiness related to physical activity before and after the ready for recess intervention? Health Education Research, 28(2), 192-204. http://dx.doi.org/10.1093/her/cys102

Ennis, C.D. (1994). Urban secondary teachers' value orientations: Delineating curricular goals for social responsibility. Journal of Teaching in Physical Education, 13(2), 163179.

Fernández Cruz, M. (1995). Ciclos en la vida profesional de los profesores. Revista de Educación, 306, 153-203.

Griffey, D.C., \& Housner, L.D. (1991). Differences between experienced and inexperienced teachers' planning decisions, interactions, student engagement and instructional climate. Research Quarterly for Exercise and Sport, 62(2), 196-204. http://dx.doi.org/10.1080/02701367.1991.10608710

Hagger, M.S., \& Chatzisarantis, N.L.D. (2016). The trans-contextual model of autonomous motivation in education: Conceptual and empirical issues and meta-analysis. Review of Educational Research, 86(2), 360-407. http:// dx.doi.org/10.3102/0034654315585005 
Housner, L.D., \& Griffey, D.C. (1985). Teacher cognition: Differences in planning and interactive decision-making between experienced and inexperienced teachers. Research Quarterly for Exercise and Sport, 56, 45-53.

Hubball, H., \& West, D. (2009). Learning-centered planning strategies in outdoor education $\begin{array}{lll}\text { programs. } & \text { Strategies, } 23(1),\end{array}$ http://dx.doi.org/10.1080/08924562.2009.10590855

Huizinga, T., Handelzalts, A., Nieveen, N., \& Voogt, J.M. (2014). Teacher involvement in curriculum design: Need for support to enhance teachers' design expertise. Journal of Curriculum Studies, 46(1), 33-57. http://dx.doi.org/10.1080/00220272.2013.834077

Joens-Matre, R.R., Welk, G.J., Calabro, M.A., Russell, D.W., Nicklay, E., \& Hensley, L.D. (2008). Rural-urban differences in physical activity, physical fitness, and overweight prevalence of children. Journal of Rural Health, 24, 49-54. http://dx.doi.org/10.1111/j.1748-0361.2008.00136.x.

Juliusson, E.A., Karlsson, N., \& Gärling, T. (2005). Weighing the past and the future in decision-making. European Journal of Cognitive Psychology, 17(4), 561-575. http://dx.doi.org/10.1080/09541440440000159

Kim, H. \& Housner, L.D. (2010). The Influence of class size on the planning, decision making, concerns, and instructional behaviors of experienced and inexperienced teachers. International Journal of Applied Sports Sciences, 22(2), 77-95.

Matanin, M., \& Collier, C. (2003). Longitudinal analysis of preservice teachers' beliefs about teaching Physical Education. Journal of Teaching in Physical Education, 22,153-168.

MacPhail, A., Tannehill, D., \& Karp, G.G. (2013). Preparing Physical Education preservice teachers to design instructionally aligned lessons through constructivist pedagogical practices. Teaching and Teacher Education, 33, 100-112. http://dx.doi.org/10.1016/j.tate.2013.02.008

Martínez-Torrón, J. (2012). The teaching of religion in Spanish educational system. Rivista di Storia del Christianesino, 9(1), 117-132.

O’Hara, K., Reis, P., Esteves, D., Bras, R., \& Branco, L. (2011). Science, sport and technology. A contribution to educational challenges. Electronic Journal of e-Learning, 9(1), 87-97.

Pajares, M.F. (1992). Teachers' beliefs and educational research: cleaning up a messy construct. Review of Educational Research, 62(3), 307-333. http://dx.doi.org/10.3102/00346543062003307 
Pasek, M., Michalowska-Sawczyn, M., \& Nowak-Zaleska, A. (2014). Changes in maximal aerobic fitness students' attitude towards physical effort during outdoor and indoor shool lessons of Physical Education. Baltic Journal of Health and Physical Activity, 6(1), 24-33. http://dx.doi.org/10.2478/bjha-2014-0003

Pissanos, B. W., \& Allison, P. C. (1993). Students' constructs of elementary school physical education. Research Quarterly for Exercise and Sport, 64(4), 425-435. http://dx.doi.org/10.1080/02701367.1993.10607596

Polikoff, M.S. (2013). Teacher education, experience, and the practice of aligned instruction. $\begin{array}{llll}\text { Journal } & \text { Teacher }\end{array}$ http://dx.doi.org/10.1177/0022487112472908

Rimm-Kaufman, S.E., Storm, M.D., Sawyer, B.E., Pianta, R.C., \& LaParo, K.M. (2006). The Teacher Belief Q-Sort: A measure of teachers' priorities in relation to disciplinary practices, teaching practices, and beliefs about children. Journal of School Psychology, 44(2), 141-165. http://dx.doi.org/10.1016/j.jsp.2006.01.003

Shrout, P.E., \& Fleiss, J.L. (1979). Intraclass correlations: Uses in assessing rater reliability. Psychological Bulletin, 86(2), 420-428.

Sicilia, A., Sáenz-López, P., Manzano, J.I., \& Delgado, M.A. (2009). El desarrollo curricular de la Educación Física en Primaria y Secundaria: Un análisis desde la perspectiva del profesorado. Apunts: Educación Física y Deportes, 98, 23-32.

Silva, P., Sousa, M., Sá, C., Ribeiro, J., \& Mota, J. (2015). Physical activity in high school during 'free-time' periods. European Physical Education Review, 21(2), 135-148. http://dx.doi.org/10.1177/1356336X14555295

The Outdoor Fundation (2013). Outdoor Participation Report 2013. Colorado, CO: Outdoor Foundation.

Timken, G., \& Mars, H. (2009). The effect of case methods on preservice physical education teachers' value orientations. Physical Education and Sport Pedagogy, 14(2), 169-187. http://dx.doi.org/10.1080/17408980701718459

Van den Berg, R. (2002). Teachers' meaning regarding educational practice. Review of Educational Research, 72(4), 577-625. http://dx.doi.org/10.3102/00346543072004577

Viciana, J., Blanco, H., \& Mayorga-Vega, D. (2015). Psychometric properties of the influences on decision-making in physical education questionnaire (CIPEF). Cuadernos de Psicología del Deporte, 15(1), 285-294. 
Viciana, J., \& Mayorga-Vega, D. (2013). Análisis del cambio curricular de LOGSE a LOE en la Educación Física de Primaria. Profesorado. Revista de Curriculum y Formación del Profesorado, 17(13), 257-271.

Wilcox-Herzog, A. (2003). Is there a link between teachers' beliefs and behaviors? Early Education and Development, 13(1), 81-106. 